\title{
宇宙からみた地球環境*
}

\section{吸田俊 文**}

\section{Global Environment from Space}

\author{
Toshibumi SAKata
}

\section{1.はじめに}

人工衛星に上る地球の観測が始まってからすで に30年たっている。ロケットによる大気構造の観 測から始まり，地上からのさまざすな地球を知る 手段が今世紀になって活発になった。地球科学は 広筢な対象を科学者のフィルドサーベイ，観測船 に上る調查，探查隊に観測，種々の観測機材の開 発などによる研究報告やデータの蓄積によって発 展し多くの研究業績があげられている。この分野 に人工衛星に上る観測が泇わったことは，いま文 でにない幅広い新しいデータが得られるようにな ったと言えよう。りモートセンシングと呼ばれる 技術はこの人工衛星や航空機による画像撮影技術 汇よって地球表面の方らゆる対象物からのスペク トルや形状のデータを捉えることができるのであ る。

流れの可視化といら視点でこの人士衛星からみ た地球上のさまざまな対象物や現象がどのように 捉克られているか述べてみたい。

\section{2. 地球を観測する}

地球観測衛星として早くかから笑用化されたの は気象観測衛星である。1957年に打上げられた “スプートニク”以来，世界中で人乙衛星の打上げ の競争が始なった。特に米ン間の激しい䍵いは失 敗を連続しながら徐々に技術を问上させ，さらに， 両国間の打上げ競争が続いた。1960年初頭になる と米国の気象衛星の打上げが始まり，TIROS：

*原稿受付 昭和63年 2 月17日

**東海大学情報技術センター
リーズのスタートになった。このTIROSに続い て，ESSA，NOAA (ITOS) と1970年代の終り まで続くことになる。さらにTIROS-N として新 しいNOAA が軌道に送られ現在10号までが運用 されている。この NOAA は，極軌道衛星として 高度約 $800 \mathrm{~km}$ で $3,000 \mathrm{~km}$ 幅の地表を撮影して和 り，世界の広城のデータを捉えているもっとも利 用度の高い衛星になっている。1960年代の後半に NIMBUS といら父像衛瑆が計画されオン゙ン, 紫外線, 海温分布，太陽エネルギーなどの観測機 材を塔載した衛星が開発され，垷在もとの7桨が 軌道上にある。静止軌道の気象衛星は1974 年に GOESが打上げられ，“GMS”ひまわり，つで METEOSAT, INSAT が軌道上飞配置された。 1972年飞 NASA は地球資源探查技術衛星 “ERT S”を初の気像衛星以外の観測衛星として打上げ た。このERTS 現在LANDSAT と呼ばれて いて，現在 4 号战よび 5 号が軌道上にある。この LANDSATはNIMBUS とほとんど同じ形のも ので NIMBUS の塔載センサーを变壳たもので, 3 学玉で運用した（1960年代から開発されてき た多くの塔載センサーの改良されれたるの゙この LAN DSAT K載世られ奏用衛星として利用さ れている)。

LANDSAT は極軌道太陽同期の衛星で 1 号か ら3 号までは高度約 $900 \mathrm{~km}, 4$ 号からは約 $700 \mathrm{~km}$ で地球一周が90分から110分程度で周四している。 地上の撮影は地上解像力が $80 \mathrm{~m} の$ MSS (Muti Spectral Sensor) と $30 \mathrm{~m}$ の TM (Thematic Mapper）のセンサーを塔載して括り，地上幅を $185 \mathrm{~km}$ を秒速約 $8 \mathrm{~km}$ 弱でスキャニングしてい 
る。スペクトルの幅は可視, 近赤外特よび熱赤外 までをMSSで 4 バンド，TMで 7 バンドにわけ て撮影し，地上の受信局へと送信している。LA NDSAT が1972年以_15年間にわたり観測した 地球上のあらゆる対象物の姿から実代さまざまな 多くのデータが得られ，貴重な成果をもたらして いる。

この LANDSATはその後地球観測の幅法いデ 一タの取得から画像処理技術を含めたリモートセ ンシング技術を発展させた地球観測の分野での関 心を骨めた。1985年になりフランスは“SPOT” という地球観測衛星を打上げた。この衛星は地上 解像力 $10 \mathrm{~m}$ といら高解像力の七ンサーを塔載し, LANDSAT 以上の能力に関心が持たれた。さら に1987年に日本の地球観測衛星 “MOS-1” が軌道 に載せられた。ここの衛星の特徵は海洋観測衛星 と呼ばれ，1978年に初の海洋観測衛星として打上 げられ，わずか3かてて停止した米国の“SEA SAT”に次ぐものである。この MOS-1 は試験的 な垁用衛星としての側面が強く, MESSER と呼 ばれるセンサーは解像力 $50 \mathrm{~m}$ であるが，2台の カィラを持り交互に運用できる。また，VTIRは 可視熱赤外七ンサーで, $0.9 \mathrm{~km}$ および $2.7 \mathrm{~km} の$ 解像力で $1,500 \mathrm{~km}$ の幅の範囲を観測できる。 $\mathrm{SR}$ はマイクロ波放射計で $23.8 \mathrm{GHz}$ 执よび 31.4 $\mathrm{GHz}$ の 2 波長受動型の七ンサーを塔载し $317 \mathrm{~km}$ の円形を観測するものである。LANDSATとの 交換性のあるデータ, NOAAのもつ広城探査用 の特徵と試験的なマイク口波放射計の三つの特長 あるセンサーをもっている。

気像衛星 N-NOAA は1978年にスタートしたシ リーズ TIROS-Nで，常時 2 個を組合わせて極 軌道で観測している。さまざまな衛星があるが， 現在では上記の代表的な衛星によって地球の環境 観測が常時できるようになりつつある。静止軌道 上の気象衛星 5 個，極軌道上のNOAA 2 個，同 じく極軌道上の LANDSAT, SPOT, MOS $の 3$ 個による地球観测が何らかのデータリンクによっ て地球全体の動きを観測できる。次期衛星として 資源探查衛星が1990年代に予䇥されていて，日本 およびョーロッパでJ-ERS, E-ERSの名でそれ ぞれ打上げられる。これらの計画では，雲や水蒸
武の吸收のないマイクロ波領城で全天候の合成開 ロレーダーが塔載される。

このように，つぎつぎと地球観測に対して衛星 の利用が高まっているが，その理由の第 1 として 常時広城を観测できることで地球表面の大気の流 れ，海流の動き，熱の分布，植生の変化，砂漠の 扗大などが従来の観測手段とは異なり，地球的規 模でネットワーク化できるからである。このた め, 衛星の大型化や寿命の延長, 燃料の補給, 人 ンテナンスなどのため極軌道プラットホームやス ペース基地が考它られている。

\section{3. 動く大地}

地球の誕生から46億年といわれる地球の表面は 地表や大気の安定によって徐々に変わってきた。 大陸と海洋は何億年もの間, 変化の激しい移動を 繰り返して和り今後も続くであるう。常時に長い 将間のスタールで考党ると地表はマグマの上をゆ っくりした流れの状態にあって大陸は常に移動し ている。このような大陸の移動すなわち流れの状 態は地形の上に現われ，大断層や山脈の形成にそ の流れの姿をみることができる。約 6 億年前のカ ンブリヤ紀以降の地質は生物を指標として現在で は相当詳しくわかってきて扣り，古生代，中生代 の岩不の分布やジラ紀や白亜紀に招きた造山運 動，もちろん新生代化入って扣きた造山運動を含 めて地球観測衛星が捉えた地表のさまざまな姿に み壳ている。

大規模な地表の構造線は大陸の上に多くは直線 状にみることができる。山脈や地溝は衛星の地上 解像力が LANDSAT の $80 \mathrm{~m}$ から $30 \mathrm{~m}$ になって より明確になり，ステレオ撮影によって立体視が 可能になり, 線状構造 (リニアメント)がよく見 える。

ウェゲナーによって提唱された大陸移動説は近 年になってプレートテクトニクスの理論やグロー マー,チャレンジャ号による海底堀削調查によっ て明確に支持されるようになって地上の形状との 関係が知られるよらになった。この結果, アフリ 力東部の大地溝带，ヒマラヤ山脈に対するインド 覀大陸の圧縮，アンデス山脈，アフリカ大陸と南 米大陸の形状などがLANDSAT によって見るこ 
とができるようになっている。現在も年に数セン チずつ動き䅐ける大陸や島がプレートの上に乗っ てマグマの上で流れているわけである。このわず かな流れは地上のいくつかの観測点で準星の電波 の信号を受け，その時間差によって年間の移動が 計れるようになっている。超長基線電波干涉計 は, VLBI (Very Long Baseline Interferometer）と呼ばれ，大陸の移動をセンチメートルの オーダーで計ることが可能になり大陸移動を裏づ けている。インド大陸が 6500 万年前に南極大陸の 位置から移動し，ヒマラヤ山脈の位置に衝突し， 現在もとマラヤ山脈を押しあげて扣り，また，八 ワイ諸島が西方に移動し日本列島に近づいている のである。

気象衛星 NOAAからのデータをコンピュー タモザイクすることによって世界全図を作るこ とができるようになった。写真 1 は人工衛星ノア (NOAA) で撮影した $3000 \mathrm{~km}$ 幅の画像をコンピ ニータモザイクしィルカトール図法に展開したも ので，(1)は雲のデータを加えたもの，(口)は雲のデ 一タを除去したもの，(少は海底地形を加えたもの である。メルカトール図法に展開したこの衛星か らの地球全図から雲を除去すると, 大陸の地形と 植生を明瞭にみることがでさる。

この地形図は観測波長域の組合わせによって植 生分布を表示することが可能で，その結果から地 表の水分や植物の状沉を知ることができる。この データから砂漠の分布が帯状になって北半球执よ び南半球ともに桩がっているのが見える。北半球 は赤道から緯度で約10度から30度ぐらいの所は砂 漠状になって西から東へとつながっている。サハ ラ砂漠から中近東を通って中国のタクラマカン砂 漠に至る。また太平洋をこえてアメりカ西部のア リゾナ,メキシコに至る地域である。一方，南半 球はフフリカのナミブで砂漠からオーストラリ ア，チリと北半球と同じく同緯度の帯状の砂漠が 続いている。乾期と雨期ではこの砂漠带は変動し サへル地帯がサハラ砂漠では北上または南下しそ の幅は数百キロメートルに達する。また，気候の 変化によって緑の帯は桩がりを变える。

森林の生態は気温や大気によって変わるが，最 近では人間の活動によるところが多い。アマゾン
は地球上では極めて大きい森林地帯である。この 地域では開拓によって急速に森林が減少してい る。LANDSATからみた森林地帯の一部ではわ ずか 5 年間で道路沿いの地域が大規模に開拓さ れ，回復不可能まで土壤が失なわれている状況が みられた。同様のことが大なり小なり地球のあち らこちらでみられている。

かつて地上に落下した大きな隕石のあともみら れる。植物に覆われた地域では不明であるが，砂 漠やッンドラ地帯ではしばしば見出されることが ある。大きさは航空機では発見されなかったが衛 星で見つかることがある。カナダやアフリカで大 隕石穴とみられるものが LANDSAT で撮影され た。

地球上の人間活動は年々規模が払大してゆく。 その典型的な例が都市の変化である。古代の都市 は消隇してもその痕跡は残り，現在の都市は拡大 を続けている所が多い。人間の歴史の流れは都市 を作りそして消隇させてゆく。都市のスプロール 現象は衛星データから観測されている。

\section{4. 海洋の流れ}

海は地球の表面の70\%を占めている。地球が太 陽系の惑星のなかで最る特異なことは，酸素を含 んだ大気と海を保有していることである。回転す る地球の表面には海の動きがあり，海の流れのパ ターンと複雑な現象によって熱エネルギーが運ば れている。写真 2 は日本列島に沿って流れる黒潮 の動きをみたものである。

太平洋, 太西洋としてインド洋と代表的な地球 上の大きな“くぼみ”とそれ以外の全地球の海水 量は 130,000,000トンと推定される。海の全世界 の平均深度は約 $4,000 \mathrm{~m}$ で大陸の高さとは較べも のにならない。海底の地形は意外に変化に富んで いて海溝，海膨，海嶺があって太洋底はさまざま な物質の堆積層に覆われている。海溝部の最深部 は10,000メートル以上あり，太洋底で広がった部 分は平均 $4,000 \sim 6,000$ メートルの所である。水の 運動は粘性からみて移動性に富んでいるので, 地 球の回転運動に極めて大きな影影を及ぼし，月の 引力による潮の干満にも関係してくる。しかし， 衛星による钼測では海の表面のみであって，内部 
(1)

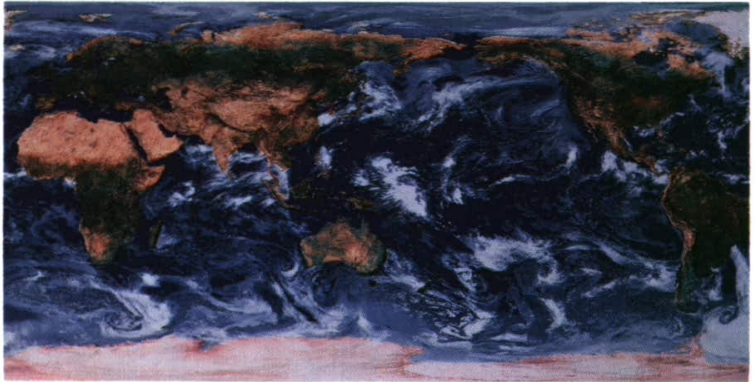

(ㅁ)

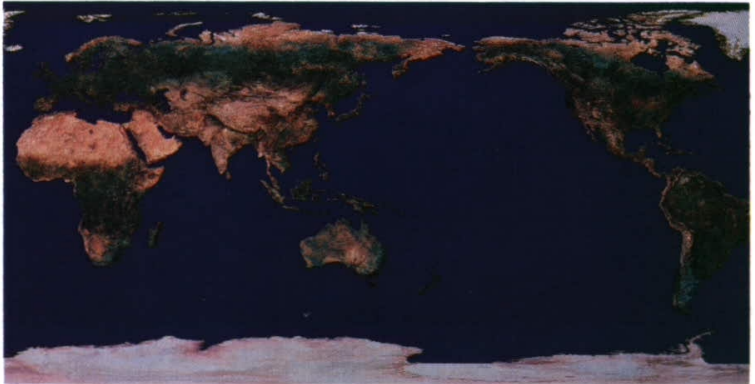

(4)

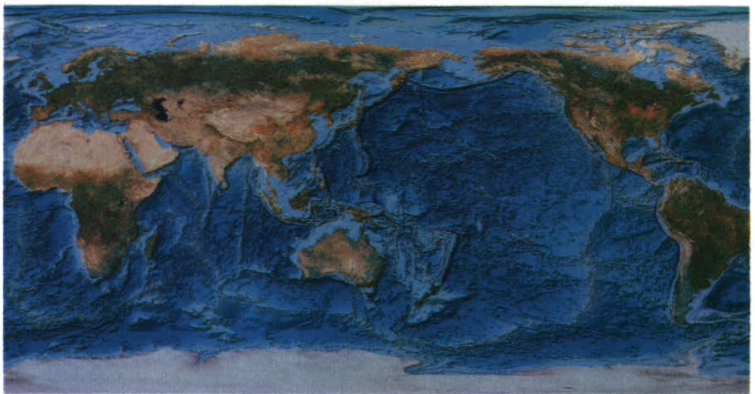

写真1 気象衛星 (NOAA) データのコンピュータモザイクによ る全世界図

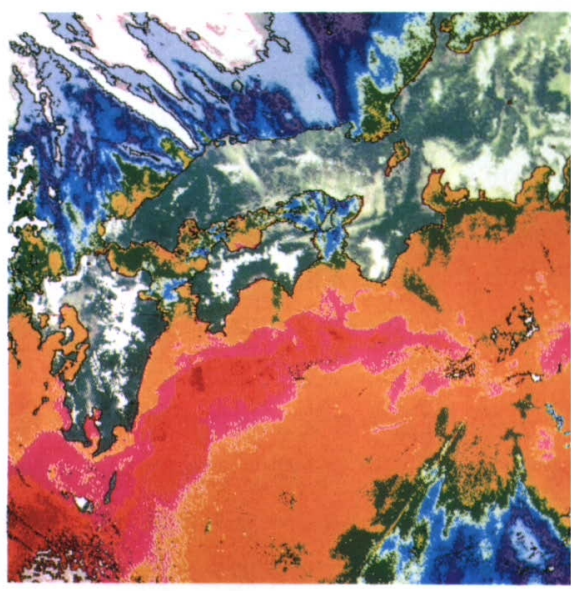

写真 2 日本南岸太平洋の黑潮のパターン

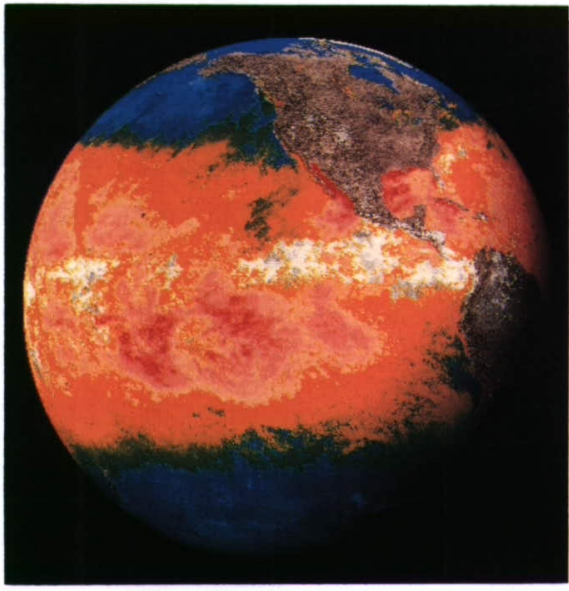

写真 4 赤道を中心にした地球の温度分布

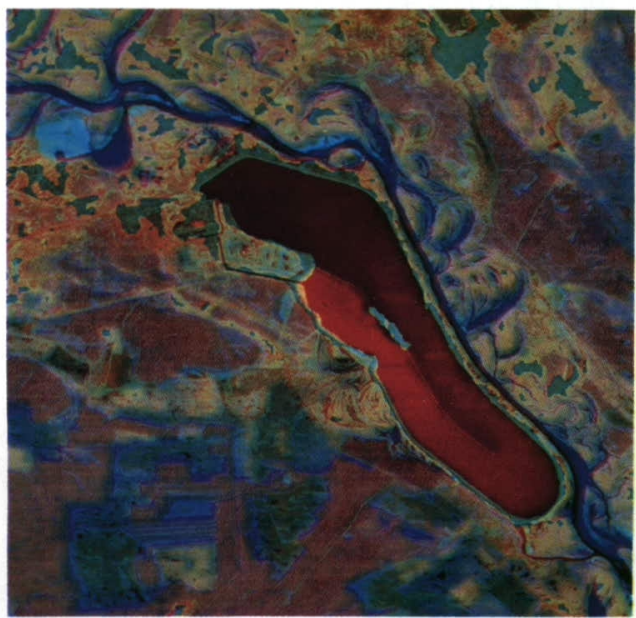

事故前

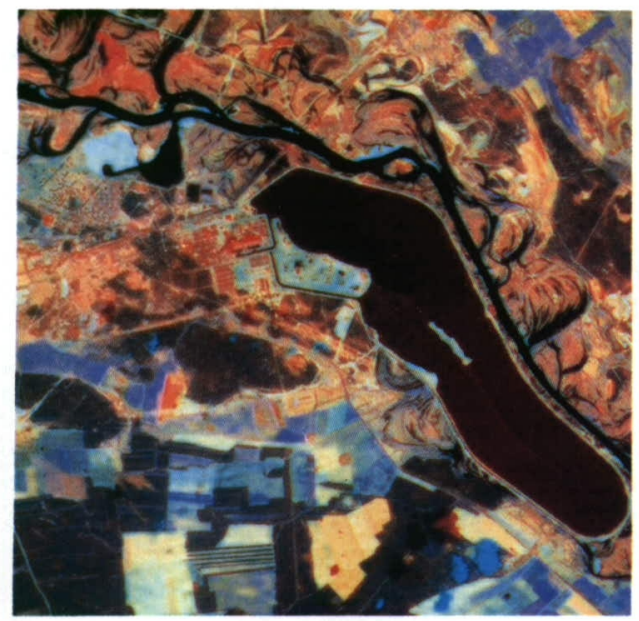

事故後

写真 7 ソ連のチェルノブイリ原子力発電所の事故 
の動きは間接的にしか知ることができない。

海の動きは，表面での動きと断面方向での動き に大きく分けることができる。これらの動きを支 配する条件として, 地球の回転と太陽の照射ェネ ルギーによる対流，そして大気との相互作用があ る。海流の動き, 特に表面では風によって動きは 複雑になっている。衛星による地球観測のなかで 最も注目され期待されるのが，この海流の動きで ある。広域で熱の運動の激しい低緯度帯から高緯 度帯までの動きを連続に観測できることは，調查 船による点の観測から衛星による面への観測へと 飛踓的にかえたのである。

赤道を境にして北および南半球はそれぞれ対象 的な変化をするが，大陸の多い北半球は南半球に 較べ複雑であり，海底の地形とも関係してくる。 地球の回転に伴い両半球では熱帯から亜熱帯にか け時計回り，または反時計回りに流れる。この結 果, 太陽からの熱は海水の蒸発と吸収によって熱 エネルギーを海流とともに北上または南下させ る。静止衛星は雲の動きに主点がおかれるが, 熱 分布を広域にみることができる。一方，極軌道衛 星は低高度で海流方向と海水温をみることができ る。しかし，海水温は直接測温したものとは隔り があろら。その一つは大気補正が極めて重要で, 衛星高度までの垂直方向の大気の分布と水蒸気な どの吸収の補正が必要である。その二は表面海水 温が下層の構成によって異なるからである。

垂直面での海水の動きは太陽により温められた 海水は極方向に動き，冷却されて下層から再び赤 道にもどる。一方, 2,000 メートル近い所では亜 寒帯深層流があって極方向から赤道に向かってい る。さらにこの下層部は赤道から極方向に向かっ て深層流が動いている。底層流は極方向から赤道 に向かって扣り，地極全体の海底はゆっくりと海 水が流れ南極，北極とも長い時間をかけて海水で 結ばれている。海水温は表面に近い所では温度差 が少なく，中層で急速に低下し以下は一定温度に 近ついている。海流の動きの激しいのは赤道付近 で,この移動分を補うため，下層部から供給され てくる。これを湧昇流と呼んでおり，大洋上で何 か所かがよく知られている。すなわち，北米の西 海岸, 南米の西チリ, ペルー沖, アフリカの北西
および南西の沖，赤道に沿った海域および日本の 近海である。

この湧昇流には多量の栄養塩類が含まれ，それ によってプランクトンと魚が集まり漁場となって いる。このようなことから人工衛星は海面の温度 分布と海流の方向，スペクトル分布によってプラ ンクトンを観測している。写真 3 は土人衛星 NO AA によって日本列島周辺海域の海流の温度分布 を観測したもので，色のステップは約 $1^{\circ} \mathrm{C}$ に対応 している。NOAA のデータは海流の動きの観測 に最も適して拈り， NIMBUSでは CZCS (Coastal Zone Color Scaner) によって多くのデー タが取得されている。漁場の観測として海水温が 極めて重要で漁船ではこのデータを利用している ものが増觉ている。潮目境もよく検出され, 漁群 探知として今後に期待されている。一方，陸域か ら海へ流出する河川水も多量の栄養分に富み, 海 水への拡散によって漁場に大きな影響を与える。 しかし, 工業廃水, 生活污水, 発電施設からの温 廃水が過剰になると海水污染となり, 広く海洋へ 拡散してゆく情況がみられる。地球的規模で最も 注目されているのが温度分布で海面の温度パター ンがェル・ニーニョの動向が重要である。異常気 象によって引き起こされる環境変化は，干ばつと 洪水の局地化, 水不足, 食糧の生産性などに影響 を与える。このような点で衛星データは極めて強 く期待されている。

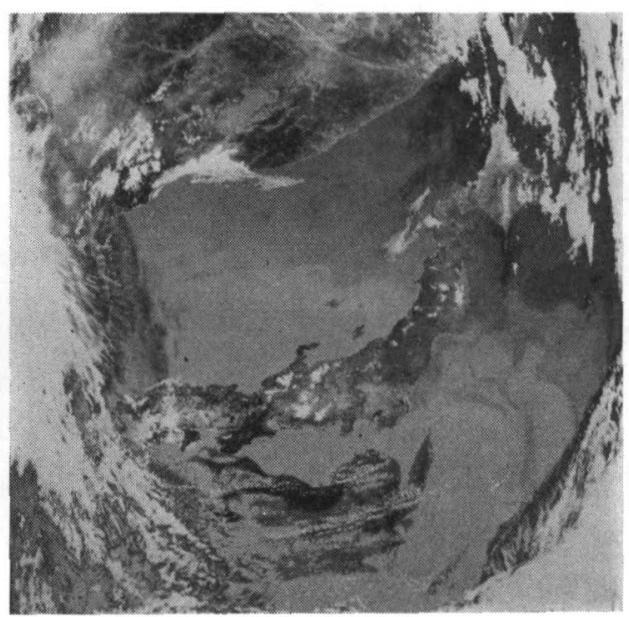

写真 3 日本近海の海面温度 


\section{5. 大気の流れ}

地球を覆う大気は太陽から到達する強烈なエネ ルギーを吸収, 反射するいわば地球の衣バリヤー である。この地球を包む大気は地表から順に対流 圈，成層圈，中間圈，熱圈として分類されている。 このらち対流圈は温度と湿度が生物に適してお り, 海や湖水, 河川からの蒸発する水分を含み, 太陽エネルギーの吸収も温和である。この対流圈 の厚さは季節や緯度によって異なるが，赤道上空 で $18 \mathrm{~km}$ で極上空では $10 \mathrm{~km}$ に達している。写真 4 は赤道を中心にした地球の温度分布で大平洋の 中心部の海面に高温部分が観察される。

太陽から照射するエネルギーは赤道上で最も強 く, その結果海洋から多量の水分を蒸発させる。 上昇した水分は雲となり, 上空で冷却されて雨と なる。そして，多くの雲は北上または南下して地 球全体を覆うのである。この結果, 熱分布と地球 の回転によって大気の動きがあり, 雲が流れてゆ くのである。強く太陽からあたためられた雲は多 量の水分を含み，台風や八リケーンとなって雨を 降らせる。竜巻は，激しい上昇気流によって地上 のあらゆる物質を空中に吸い上げる。人と衛星か らみる大気の動きはこれらの姿を捉えている。

静止軌道上飞ある気象衛星からは刻々と湧き出 すような雲, 移動する雲の動きが捉えられている。 1 時間また 3 時間ごとの映像を連結し再生すると 雲の発生と消減がよくみえる。雲の動きは地形に よって異なり，局地的な気象が作られる。

対流圈の温度分布は地上からの高さによって徐 々に低下する。したがって雲の温度分布によって 雲の高さが推定できる。しかし，これも海面や陸 上で異なり, 大気の断面方向の構造によって補正 が必要になる。対流圈上層の成層圈は対流はほと んと゚なく，温度はあまり大きく変化しない。この 成層圈の中央部は紫外線の吸収するオゾン層があ る。人工衛星 NIMBUS による長い間の観測結果 は極めて重要である。この衛星の塔載したTOM (Total Ozon Measurement) が連続した観測の 結果，この 10 年間で南極上空のオゾンの減少率は 極めて高いといら結果を示している。すでにその 中心部では $40 \%$ 以下に達していて地表の生物が直
接あびる紫外線が増加し，皮膚に与える影響が大 きく生物の生命にとって極めて重要である。最 近，極地域に見られる太陽エネルギーの変動や生 物に与える影響の研究が望まれている。

可視扣よび熱赤外スペクトルによる熱分布は地 表の気候，また環境状態を示している。赤道付近 で発生した台風は北上する途中で加速されてェネ ルギーを蓄え大型化し陸地を襲うことになる。写 真 5 は人工衛星から台風の姿を捉えたものを立体 表示したものである。日本列島にシーズンになる とやってくる台風も，フロリダ半島を襲らハリケ ーンも同様である。一方, 陸地があたためられるこ とによって起きる急激な対流は，竜巻を起こして 多くの被害を地上に与える。赤道近くの海面をも つ地域ではモンスーン地带と呼ばれる激しい気流 の動きによって大量の雨と暴風雨に見舞われる。 インドからバングラディシュ，東シナ海，日本列 島がいわゆるアジアモンスーン地带のよい例であ る。静止気像衛星 GMS ひまわりは, この地域の 雲の動きを観測する役割にもっとも適した位置に ある。一方，“GOES-East” は西インド諸島から フロリダ半島, メキシコ湾にかけての地域をみて おり，上述のハリケーンの動きを観測している。 このよう飞静止衛星による雲の動きは $36,000 \mathrm{~km}$ 上空から地球の全球をみて扮り赤道を中心とした 南北半球の状況を一度に捉える最も効果的な方法 である。

モンスーン期のインドから日本列島にかけての 雲の動きは興味深い, アラビア海, インド洋から の多量の水分と熱を含んだ雲がインドのデカン高 原にかかり，ペンガル湾を北上した雲がヒマラヤ

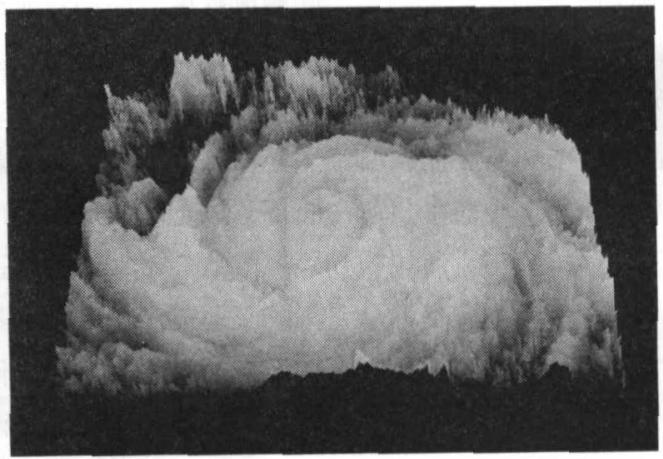

写真 5 台風の立体表示 
山脈にはばまれて東シナ海にでる。さらに北上し て日本列島にかかって梅雨による状況がひまわり の画面に刻々と写した゚されている。気象衛星“NOAA” は詳細な雲の動き, 形, 温度分布を撮影 し ていて陸地にかかる陸の動きをより明確に示して いる。

火山の噴火が大規模な場合には地球規模での影 響がある。古くは浅間山の爆発は世界的に寒冷化 の影響を与えたと言われ，近くはェル・チョチョ ンの噴火は 3 日間で噴煙が地球を覆った。三原山 の噴煙もNOAA で捉えられている。口絵 1 は大 島三原山の大噴火を爆発 3 時間後（1986年11月 21 日午後 7 時) 飞人工衛星 NOAA から赤外線 セン サーで捉光画像処理したもので，噴煙が東へ 800 $\mathrm{km}$ 以上ひろがっているのがみえる。地球規模の このような大気の動きは多くの粒子が地球規模で 浮遊して扣り, サハラの砂もヨーロッパはもとよ り太平洋や太西洋の上空で採取される。中国の黄 砂も日本には季節風によって全国に飛来して物 り,これらも衛星画像で捉えられる。

\section{6. 地球の環境}

回転する地球の表面には, 固体の大陸, 液体の 海洋, 気体の大気がそれぞれ三つの相が相互に関 係して流れの動きをもっている。もちろんその動 きの速度は異なるが，これらは太陽からのエネル ギーの吸収と反射を絽返していて, 吸収されたエ ネルギーは大きく熱エネルギーとして地球上に分 布される。写真 6 に気象衛星 METEOSAT（静

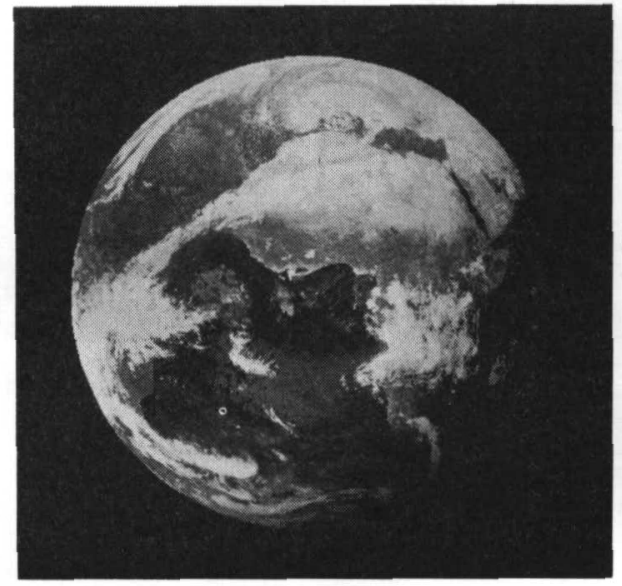

写真 6 雲の動き

止軌道衛星）が撮影した雲の動きを示す。地球の 平均気温の $1 \sim 2{ }^{\circ} \mathrm{C}$ の 差は気候に大きく影響を与 光生物の生命を支配してしまう。太陽エネルギー が常に照射される赤道では常に海面から水分が蒸 発しており，海流の循環の大きなエネルギーへと 変換される。地球規模の流れは大気の流れ, 海流 の動きと熱分布の重なったものとしてみえる。人 工衛星に塔載するセンサーは可視域から熱赤外領 域までをバンド別に検知する。また，最近ではマ イクロ波領域での放射，吸収，反射による観測が 進められている。

積雪, 流氷の状況は気象の分析にとって重要で あるばかりでなく，水資源による社会への影響が 大きくなるので，これらの動きについて常に観測 が欠かせなくなっている。同様に氷河の前進や後 退も長期的な気象予報に極めて重要な情報として 注目されている。

自然災害は台風による洪水，大規模な河川の氾 濫などは季節によって，また，火山の噴火は長期 的な周期によって, 異常気像による干ばつや砂漠 の桩大など地球上の変化は非常に多くさまざまで ある。一方，都市化による温度上昇，スモッグ， 排水，污染などは人口の増加とともにますます激 しくなっている。また，都市への人口集中による 市街の拡張は急速で, 自然の状熊の変化ははなは た゚しい。

人為的な自然の破壊は都市だけでなく，森林の 破壊を招いている，カリマンタンやアマゾンに拉 ける森林の伐採の現状はかなり深刻で，気象にも

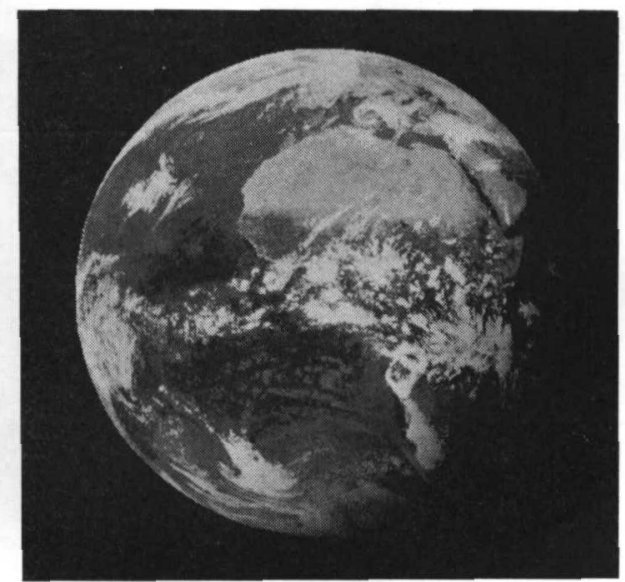


いずれ影響してくるだろう。アマゾン奥地の開拓 による森林の伐採はこの10年でまったく地表の様 相を変えて扣り，土壤の流失が進んでいるよらで ある。一方, 砂漠の拡大は年々激しくなってお り，これらを人間の手でとどめることは極めて困 難になってくるだらう。このような植生の変化 は, NOAA 衛星によって得られるVegitation Index を用いて分布図が世界地図の上に表示さ れるようになった。これらのデータから世界の環 境の変化を時系列でみることによって種々な予测 が行われている。

人為的な事故の例としてり連の原子力発電所 “チェルノブイリ”があげられる。1986 年 4 月に 起きたこの事故は，アメリカのスリーマイル島に 次ぐ社会的な重大事故でその後遣症は長く続くで あろう。この事故では人工衛星による観測が有効 な手段となった例である。事故発生（1986年4月 26日）から3 日後に LANDSAT が, 続いて SPOT (ともに地球観測衛星として高解像力 $30 \mathrm{~m}$ と $10 \mathrm{~m}$ のセンサーを塔載している）が事故現場の上 空を通過し，極わて明確な映像を捉えた（写真 8 ）。事故前の温排水は冷却池の水温より $5^{\circ}$ 位高 いが，事故後ではこの温度差がみられず原子炬の 停止状態が表わされている。事故を起こした原子 炉の温度分布と, 冷却池の温度分布も観測するこ とができ，事故の状沉を正確に把握することがで きたのである。

このように地球上で起きるさまざまな現象や変 化を刻々と捉光状況を分析でさる手段として，人 工衛星による観測手段が実用化されるようになっ た。リモートセンシング技術は複合的な技術であ り，その応用分野は広く学際的である。また，画
像から情報を抽出し解析する技術もこれらのなか でその価値を大きく認められたものである。

不可視画像を可視化する技術のなかで，X線画 像は医学のなかで大きく評価され今日 Computer Tomography として新しいステップを踏んでい る。一方，赤外線画像は熱領域を広く捉え地球規 模の大気や海洋の流れを可視化することで成功 し, 現在ではマイクロ波領域のパターン情報の実 用化が進しでいる。

\section{7. 結 び}

流れを可視化するといら視点で地球観測を考兄 てみたのであるが，非常に対象が広いのでまとま りがつかなかったかと思われる。36,000kmから $700 \mathrm{~km}$ ぐらいの上空から数 $10 \mathrm{~m}$ の解像力を得る ための衛星塔載のセンサー, また, 衛星自身の軌 道の精度からみてこれを画像するには多くの技術 的な難かしさがある。これらを実現させるための 地上の受信系, 画像処理系のハードウェア扣よび ソフトウェアの開発に負らところが極めて大き い。最終の画像化までのプロセスが意外に時間を 費していることを付汁加壳たい。

\section{文献}

1）双田俊文：日本機械学会誌，90，823 (1987).

2）"：月刊地球, 53, 11 (1983).

3) ": 写真測量とリモートセンシング,' '81特集(1981).

4) " : " '83特集(1983).

5）“：環境技術，12，5（1983）。

6) 竹内 均, 坂田俊文: 宇宙からみた日本列島, 日本放送出 版 (1983).

7）日本りモートセンシング研究会編：画像の处理と解析, 共 立出版 (1983).

8）坂田俊文, 中野尊正：日本列島地図帳，日本放送出版 (1985). 